\author{
Samanta Kowalska
}

\title{
Freedom of Speech in the Face of Terrorism - Selected International Law Regulations
}

\section{Introduction}

Freedom of speech constitutes a legal and axiological frame of a democratic society. It plays an important role in the expression, development and creativity of individuals. The public sphere is a space of exchange of information, ideas and views, which helps detect and prevent social pathologies. Preventing the spreading of views with negative connotations is so important that Article 20 of the ICCPR ${ }^{1}$ obliges the signatory states to impose a statutory ban on war propaganda and the proliferation of national, racial and religious hatred which incites hostility, discrimination and the unjustified limitation of the freedom of expression. The propaganda referred to in Article 20.1 may be examined in the context of internal and external conflicts. ${ }^{2}$ The ICCPR does not define the terms "propaganda" and "war". The wording of the above-mentioned article does not, however, paralyse the development of a national strategy and security policy. The legislative work has been conducted with a view to preventing the repetition of the events, which lead to immeasurable human tragedy and terror during World War II.

21st century terrorism is a hybrid, asymmetrical and amorphous phenomenon which escapes all attempts at description and analysis. Terrorism poses a hindrance to public discourse. It is responsible for deformation of events, and wreaks informative and semantic havoc. ${ }^{3}$ Terrorist propaganda breeds violence, terror and hatred. Conducting attacks remotely, without direct confrontation makes the modus operandi escape the defi-

1 International Covenant on Civil and Political Rights (ICCPR) open for signature in New York on 19 December 1966 (Dz.U. 1977, no. 38, item 167).

2 A. Gliszczyńska-Grabias, Zakaz propagandy wojennej, in: Międzynarodowy Pakt Praw Obywatelskich (Osobistych) i Politycznych. Komentarz, ed. R. Wieruszewski, Wolters Kluwer Business, Warszawa 2012, pp. 505, 506.

3 B. Hoffman, Oblicza terroryzmu, Wydawnictwo Bertelsmann Media, Warszawa 2001, p. 28. 
nition of "war" and "armed attack" as it is stipulated in Article 51 of UNC. ${ }^{4}$ The above aspect influences the manner of interpreting "the right to self-defence" ${ }^{5}$ and the determination of the international responsibility of non-state actors. ${ }^{6}$ Terrorist organisations which use the media and communication technology may destabilise the functioning of states and generate chronic fear in society. The technologies used by the terrorists are being modernised and pose new threats to individuals.

The threat of international implications is related to attacks conduced in the virtual world, but with consequences in the real world, e.g the severance of diplomatic relations between the Gulf States and Qatar, which took place at the beginning of June 2017. ${ }^{\text {Ac- }}$ cording to the Qatari Attorney General Ali Bin Fetais al-Marri, the situation was caused by a hacker attack on services belonging to the Emirates press agency. Negative comments of the Qatari emir regarding the states in the Gulf region appeared online. Saudi Arabia issued to a statement in which Qatar was accused of supporting terrorist organisations with the use of the media including the TV channel Al-Jazeera, ${ }^{8}$ which has its headquarters in the country's capital, Ad-Dauha (Doha). Terrorist violence reaches extreme forms. Increasingly more often the attacks are of a non-military nature. Terrorism turns words into actions, which threaten the various spheres of freedom and safety.

\section{The Essence of Freedom of Speech in the Context of Anti-Terrorism}

Article 19.1 of the ICCPR states that everyone shall have the right to hold opinions. Utterances might be verbal, written or artistic. Expressions may be as varied as human perception itself. Freedom of speech does not mean that every utterance is protected by law. Statements of anti-Semitic, racist and xenophobic nature, as well as those inciting or promoting totalitarian regimes, including the opinions that lay at their basis, have no

4 The Charter of the United Nations (UNC) signed on 26 June 1945 in San Francisco (Dz.U.1947, no. 23, item 90).

5 T. Gadkowski, Problematyka samoobrony na tle zakazu u̇ycia sity zbrojnej w prawie międzynarodowym, in: "Ruch Prawniczy, Ekonomiczny i Socjologiczny" 2013, issue 3, pp. 5-20; M. Kowalski, Prawo do samoobrony jako środek zwalczania terroryzmu międzynarodowego, Wydawnictwo „Difin”, Warszawa 2013, pp. 13 et seq.

6 W. Czapliński, A. Wyrozumska, Prawo międzynarodowe publiczne. Zagadnienia systemowe, C. H. Beck, Warszawa 2014, pp. 605, 745-747.

7 Qatar: The hackers come from the countries that announced the cut-off, in: "W prost" of 21 June 2017 (digital edition ).

8 Isolation of Qatar deepens. More countries cut off diplomatic relations, in: "Wprost" of 5 June 2017 (digital edition). 
place on "the free market of ideas". ${ }^{9}$ Freedom of speech also does not pertain to expressions (e.g. verbal, graphic, electronic), which promote terrorist ideology, as they provide fodder for actions which threaten human rights on a global scale. Media broadcasts should extinguish, not exacerbate them. In Article 19.3 of the ICCPR it was stated that the implementation of the freedom of speech "carries with it special duties and responsibilities". Information is not limited territorially. Communication technologies facilitate the spreading of information about attacks, recruiting new members, and communicating with the use of a special code. Terrorist organisations publish hostage execution videos, which transform actual violence into media-presented violence. Terrorists strive to fill information services with their content. Media publications about terrorist attacks selectively tunnel the attention of the recipient.

The media should abstain from disseminating information, so as not to become an instrument for spreading unrest in the hands of terrorists. Media activity through the visualisation of the communicated information should not transgress the limits of the freedom of expression. The law under discussion is constructed in such a way that it ensures universal expression and creativity, while simultaneously keeping one from taking it from others, or offering a "simulacrum" of freedom of speech, which in reality would come down to introducing restrictions or artificial divisions.

There are many cultures, religions and opinions in the world. Every culture has values and symbols considered fundamental, prophetic or sacred. In 2015 the French weekly "Charlie Hebdo" featured a caricature of the Prophet Muhammad, which some people considered to be provocative, offensive for Muslims, and intended to stir up hatred and conflict. The author of the caricature, the cartoonist Renald Luzier said: "This is our cover (...), not the cover the terrorists would want from us [...]. I am not worried at all [...], I believe in the intelligence of people and the intelligence of humour" ${ }^{10}$ Freedom of speech on the legal and axiological plane is characterised by an internal logic, which oscillates around the exemplification of the essence of human rights, and not the affirmation of violence. Artists sometimes use satire and caricature to express themselves. However, caricature and satirical forms should comply with the rules of social life and have a well-founded social goal - the defence of important and universally accepted values. ${ }^{11}$ Co-existing in multicultural society requires refraining from certain behaviours when exercising one's own freedom of speech. In a democratic society media

9 A. Bodnar, M. Szuleka, Koncepcja „nadużycia prawa” w Konwencji o ochronie praw cztowieka i podstawowych wolności a mowa nienawiści, in: Mowa nienawiści a wolność stowa. Aspekty prawne i spoteczne eds. R. Wieruszewski, M. Wyrzykowski, A. Bodnar, A. Gliszczyńska-Grabias, Wolters Kluwer Business, Warszawa 2010, p. 151.

10 The new issue of "Charlie Hebdo" is out. 3 mln copies, 5 language versions, sold in over 20 countries, in: "Newsweek Polska" of 14 January 2015 (digital edition).

11 J. Sobczak, Prawo do wizerunku, prywatności i godności wobec wolności stowa, in: "Annales Universitatis Mariae Curie-Skłodowska. Sectio K: Politologia”2008, vol.XV, no. 1, p. 81. 
communications should be diverse and take into consideration ethnic national, religious and language minorities. We should build "bridges" not "walls", which divide and deepen social diversification and generate a climate of mutual animosity. The path to intercultural dialogue does not lead through abuse, libel and insults.

Limitations to the freedom of expression should have a legal basis and be compliant with the rule of law. General social interest should be balanced with the fundamental rights of an individual. ${ }^{12}$ While designing and implementing antiterrorist strategies in view of the rationalisation of limitation clauses, one should refer to the axiology of human rights. Therefore, under Article 19.3 of the ICCPR freedom of expression may be subject to certain restrictions, but these shall only be such as are provided by law and are necessary: (a) For respect of the rights or reputations of others; (b) For the protection of national security or of public order (ordre public), or of public health or morals. One may note that the terms "national security" and "public order" are subject to extensive interpretation. When fighting terrorism one may not arbitrarily infringe civil liberties. While working on the ICCPR the legislators were aware that the freedom of expression might be turned into a tool for propagating hatred and indoctrination, and for exerting pressure on a given individual or a group of individuals. ${ }^{13}$

Information distribution channels should be free of apocryphal information, comments or "troll" posts disseminated to spread chronic fear. Reporting on terrorist attacks in the media causes a psychological chain reaction - people start to fear, which may hinder the ability for constructive actions and decision-making. It may also drastically increase the social awareness of the risk of occurrence of criminal activity. As a result vigilance might be decreased unless actual symptoms pointing to a terrorist attack transpire.

Knowledge about terrorism should be verified continuously. Public authorities should not disregard indications of planned attacks, because one may never know which of the forecast scenarios might be implemented. The Berlin Christmas Market attack of 19 December 2016 might serve as an example here. The stolen Polish truck was driven to Breitscheidplatz, which is a popular location with locals and tourists. 12 people died in the attack, and 48 were wounded. The Reuters News Agency reported that the Islamic State ${ }^{14}$ (Islamic State of Iraq and Sham - ISIS) claimed responsibility for the attack. Terrorists use various means to achieve the main target: cars, underground and railway carriages, and planes. Increasingly more often attacks take on non-physical form, e.g. cyberterror-

12 A. Redelbach, Wolnośćstowa w orzecznictwie Europejskiego Trybunatu Praw Cztowieka, in "Ruch Prawniczy, Ekonomiczny i Socjologiczny" 2000, issue 3, pp. 19-21.

13 A. Gliszczyńska-Grabias, Ograniczenia swobody wypowiedzi-klauzule imitacyjne z art. 19 ust. 3 MPPOiP, in: Międzynarodowy Pakt..., op. cit., p. 481.

14 K. Sikorski, Germany: A terrorist attack on Breitscheidplatz in Berlin. A truck driven into crowds at a Christmas Fair, in "Dziennik Polska Times" of 20 December 2016 (digital edition). 
ist attacks. ${ }^{15}$ An attack may sabotage the power supply network by causing a dysfunction in the remote operation and control equipment of nuclear power plants. The terrorist toolkit also includes the electromagnetic impulse, which, by disrupting or destroying electronic circuits, may in a short amount of time paralyse the functioning of state institutions (e.g. police, banks, hospitals, airports, alarm systems) as well as international organisations. Terrorists try to blur the negative connotations of this phenomenon. With the use of media outlets they try to cause information chaos.

In Article 4b of the Convention on the Prevention and Punishment of Crimes Against Internationally Protected Persons, Including Diplomatic Personnel, ${ }^{16}$ the meaning of exchange of information and coordination of actions aiming to prevent this type of illegal act has been highlighted. Since the adoption of the Convention, the paradigm of terrorism and information and communication technologies such as Internet radio and television, and 4G mobile technology, have all changed dramatically. Many people do not see that terrorists are trying to paralyse the freedom of speech in terms of communicating and disseminating information about possible danger.

The weapons and technologies used by terrorists are modernised with the aim of causing chronic fear and terror in the society. Danger is connected, for example, with the possibility of using a biological weapon. Its trans-border nature, the possibility of it spreading rapidly, and difficulties in diagnosis, may cause a large number of casualties in a short period of time. Microorganisms and biological material may be used to poison water sources and food. Aerosols may be used to contaminate air. There have been cases of theft of anthrax and plague bacteria from research institutes in Russia. ${ }^{17}$ The threat of biological materials being obtained became so real that many renowned science periodicals, especially after $9 / 11$, begun to introduce a form of auto-censorship. ${ }^{18}$ Scientists warn that the terrorists who obtain genetic materials may, with suitable instruction, create an

15 T. R. Aleksandrowicz, Bezpieczenstwo w cyberprzestrzeni ze stanowiska prawa międzynarodowego, in "Przegląd Bezpieczeństwa Wewnętrznego" 2016, no. 15 (8), pp. 15-16. See also P. W. Brunst, Terrorism and the Internet: New Threats Posed by Cyberterrorism and Terrorist Use of the Internet, in: A War on Terror? The European Stance on a New Threat, Changing Laws and Human Rights Implications, ed. M. Wade, A. Maljevic, Springer, New York 2010, pp. 51-78.

16 Convention on the Prevention and Punishment of Crimes Against Internationally Protected Persons, Including Diplomatic Personnel prepared in New York on 14 December 1973 (Dz.U. 1983, no. 37, item 168).

17 K. Chomiczewski, Zagrożenie ü̇yciem broni biologicznej w zamachach terrorystycznych, in: Oblicza wspótczesnego terroryzmu, eds. K. Kowalczyk, W. Wróblewski, Wydawnictwo Adam Marszałek, Torun 2006, p. 165.

18 Under Article 54.2 of the Constitution of the Republic of Poland of 2 April 1997 (Dz.U. 1997, no. 78, item 483) preventive censorship of the means of social communication and the licensing of the press is banned. Article 54.2 stipulates, however, that under the act it is admissible to introduce an obligation to obtain a licence for radio or television broadcasting. It bears noting, however, that in a democratic society, which should be characterised by pluralism, the licence obligation cannot be theoretical and cannot block or make it impossible for entities to partici- 
array of viruses including virus artefacts, which do not occur in the natural environment. Terrorist organisations include groups which have laboratories and recruit specialists. ${ }^{19}$ One should note that in this context "auto-censorship" does not aim to limit the freedom of speech or the freedom to publish the results of scientific research, but to protect the data from being obtained by unauthorised persons, who could use this information for criminal purposes. When considering the definitions and typologies of terrorism one cannot stop at recognising the circumstances or the results of a terrorist attack. It is also important to look at a given attack from a broader perspective. The qualification of a given deed should be conducted as a multi-layered analysis of the situation. The circumstances in the broader sense, as well as the transformations of the terrorist paradigm should be considered.

Individual emanations of the freedom of speech are reflected in the regional system of human rights protection. The European system of human rights protection is focused around the Convention for the Protection of Human Rights and Fundamental Freedoms (ECHR). ${ }^{20}$ Article 10.1 of the ECHR stipulates the following components of the freedom of expression: a) the freedom to hold opinions, b) the freedom to impart information and ideas, and c) the freedom to receive them. ${ }^{21}$ According to the Strasbourg standards, the liberty to exercise freedom of speech should not be related to an arbitrary and disproportionate interference with the rights of an individual. Tabloids often find and disseminate information that creates an atmosphere drenched with violence. Information regarding terrorism meets the quasi-criteria, which means that in this context the exercise of the freedom of speech may encounter certain difficulties. A broadcasting narrative may serve the purpose of prophylaxis and prevention, or it may join the strategy of psychological and emotional manipulation and persuasion, propagating stances which, in truth, constitute the negation of the axiology of the freedom of speech.

Under Article 10.2 of the ECHR, exercising freedom of expression may "be subject to such formalities, conditions, restrictions or penalties as are prescribed by law and are necessary in a democratic society, in the interests of national security, territorial integrity or public safety, for the prevention of disorder or crime, for the protection of health or morals, for the protection of the reputation or rights of others, for preventing the disclosure of information received in confidence, or for maintaining the authority and im-

pate in the audio-visual market and exercise their freedom of speech. Licence systems may be used for the protection of rights and liberties of individuals when they are not used arbitrarily.

19 S. Kowalska, Prawa cztowieka a terror i terroryzm, Adam Mickiewicz University in Poznan and Kalisz Society of Friends of Learning, Kalisz 2008, pp. 49 et seq.

20 Convention for the Protection of Human Rights and Fundamental Freedoms singed in Rome on 4 November 1950 (Dz.U.1993, no. 61, item 284).

21 M. Macovei, Freedom of Expression. A Guide to the Implementation of Article 10 of the European Convention on Human Rights, Council of Europe, Strasbourg 2004, p. 8. 
partiality of the judiciary". ${ }^{22}$ One should counteract asymmetry between the provisions of the law and practice. It is assumed to be "obvious that as a human right, freedom of speech cannot be an absolute value which grants everyone the right to say anything, with disregard to foreseeable results of such behaviour. Should we do that it would stop being an instrument of defending other human rights, and become a means of their infringement". ${ }^{23}$ If by means of the freedom of speech we can strive for the truth, ${ }^{24}$ which in the context of the subject at hand means showing the actual motivations of terrorists, it takes us beyond epistemological deliberations and towards implementing practical solutions. For anti-terrorist strategies cannot be based entirely on epistemology.

In the context of anti-terrorist actions, the right to have access to information becomes particularly important. Authorities should not limit or prevent access to public information. On receiving a negative decision an individual should have the right to seek an effective legal remedy. Under Article 3.2 of the Act of 6 September 2001 on Access to Public Information (AAPI) ${ }^{25}$, the right to public information covers the entitlement to: a) obtain public information, including obtaining information processed within such a framework, in which it is particularly essential for the public interest, b) insight into the official documents, and c) access to the board meetings of the bodies of public authorities chosen by general elections. It is in the public interest to be informed about the occurring dangers. The second subsection is important from the point of view of developing and implementing antiterrorist strategies, which should have proper legitimacy and be subject to monitoring. It would allow the revision and removal of possible faults and lend legal provisions prospectiveness. The third aspect directs attention to matters regarding public safety, which may be related to certain duties being bestowed on the society or the introduction of additional safety measures. Under Article 3.2 of AAPI, the right to obtain public information should be implemented immediately. The provisions under discussion have particular meaning in the context of terrorism. Terrorism may disturb not only personal, economic or social rights, but also biological balance. The danger here is connected with attacks on tankers and oil platforms, the introduction poisonous substances to soil, water and air, or illegal transport and storage of radioactive substances, which may cause an environmental disaster of trans-border magnitude. In the Rio de Janeiro Declaration regarding the environment and development adopted

22 More: I. C. Kamiński, Ograniczenia swobody wypowiedzi dopuszczalne w Europejskiej Konwencji Praw Cztowieka. Analiza krytyczna, Wolters Kluwer Business, Warszawa 2010, pp. 21 et seq.

23 W. Wacławczyk, Swoboda wypowiedzi jako prawo cztowieka, in: Prawa cztowieka. Wybrane zagadnienia i problemy, eds. L. Koba, W. Wacławczyk, Wolters Kluwer Business, Warszawa 2009, p. 258.

24 Ibidem, pp. 247, 258.

25 Act of 6 September 2001 about Access to Public Information (Dz.U. 2001, no. 112, item 1198 as amended). 
at the United Nations Conference on the Environment and Development ${ }^{26}$ the role of an efficient warning system against disasters (principle 18) ${ }^{27}$ was highlighted. It bears emphasising that antiterrorist actions should be implemented not only ex post, but also ex ante.

The tactics of terrorism are also transformed into unexpected and ruthless forms online, where information may be stored or modified. Implications may even lead to an international conflict ("information war"). Many sites and Internet portals are not sufficiently secured against hacker attacks. The US Department of State regularly faces cyber-attacks. Cyberterrorism causes a great deal of damage: the theft of personal data, withdrawals of money from bank accounts, dissemination of viruses and the blocking of services. For example, before the commencement of the second round of the presidential elections in France it was reported that hackers intercepted and published 9 gigabytes of e-mails of Emmanuel Macron's staff. A portion of these documents had been falsified (the fabrication of data). ${ }^{28}$ The Internet is a source of information, however in the hands of cyber-terrorists it may be employed to spread disinformation.

The European Court of Human Rights (ECHR) analysed the freedom of speech in the context of electronic media in the case of Youth Initiative for Human Rights v. Serbia, 2013. ${ }^{29}$ It was stressed that the officials, while fulfilling their duties using specialist technologies, should not exceed their competences. In the above application a nongovernmental organisation asked the Serbian intelligence agency BIA (Bezbednosnoinformationa agencija) for information on how many people were under electronic surveillance at a given period of time. The applicant was denied and informed that the information is subject to privacy law. The ECHR ruled that in this case the information was crucial both for public debate as well as the protection of individual rights. The refusal was not justified.

In another case, Delfi AS v. Estonia, $2015,{ }^{30}$ the Strasbourg court analysed the matter of the responsibility of one of the Estonian Internet services for vulgar comments posted by users. The administrator should have taken appropriate steps, e.g. used anti-spam. ${ }^{31}$ Prophylaxis and prevention may be undertaken in the media in a non-arbitrary manner,

26 The United Nations Conference on Environment and Development was organised in Rio de Janeiro 3-14 June 1992. See also Convention on Environmental Impact Assessment in a Transboundary Context signed in Espoo on 25 February 1991 (Dz.U. 1999 , no. 96, item 1110).

27 M. Balcerzak, Ochrona osób w przypadku katastrof. Uwagi o projekcie Artykutów Komisji Prawa Międzynarodowego Organizacji Narodów Zjednoczonych, in: Kierunki rozwoju wspótczesnego prawa międzynarodowego, ed. K. Karski, Wydawnictwo „Bellona”, Warszawa 2015, pp. 90 et seq.

28 Another hacker attack during elections. E-mails of Macron's staff leak out, in: "Wprost" of 6 May 2017 (digital edition).

29 Application of Youth Initiative for Human Rights v. Serbia, 2013, no. 48135/06.

30 Application Delfi AS v. Estonia, 2015 r., no. 64569/09.

31 S. Kowalska, $W$ poszukiwaniu ochrony przed bezprawnościq i arbitralnościq - strasburskie standardy praw cztowieka, Wydawnictwo „K \& HP”, Poznań 2014, pp. 149 et seq. 
when it is "necessary in a democratic society" as it was established in the judgement of 30 May 2017 in the case Carlos Trabajo Rueda v. Spain. ${ }^{32}$ Therefore, these actions should be implemented on the vertical and horizontal plane.

It bears highlighting that the point of reference in those cases should be human dignity, which is a guideline not only in the scope of meeting legal obligations, but also moral duties. ${ }^{33}$ It should motivate the adoption of appropriate stances characterised by respect for the freedom of expression and the proper explanation of antiterrorist strategy.

In the context of antiterrorism one cannot disregard the prevention of radicalisation of the public mood. Actions in that area should be implemented starting with local communities, as it is there that the detection, uncovering and identification of such phenomena is the easiest. The role of subsidiarity is especially evident in this context. The idea of subsidiarity was set out in the Protocol on the Application of the Principles of Subsidiarity and Proportionality to the EU Treaty, in which it was stated that the decision process should take place as close as possible to the inhabitants. ${ }^{34}$ The principle of subsidiarity may be applied both in the case of law-making, as well as the application of law. In the context of this paper it creates a space for compromise between the international and regional systems of human rights protection. ${ }^{35}$ Society is where public interest and individual interests clash. In order to protect citizens against a terrorist attack, a decision might be taken to interfere with their rights and liberties, e.g. with their private life and freedom of expression. In case of the application of Margaret Murray et. al v. Great Britain, ${ }^{36}$ the army entered private property without a warrant. The house was searched, information gathered, photographs taken. Two brothers of the applicant had previously left for the United States, where they were sentenced for crimes related to the purchase of arms for a terrorist organisation. The applicant was suspected of collecting and transferring money for the purchase of arms for the Irish Republican Army. The European Court of Human Rights stated that in the

32 Application Carlos Trabajo Rueda v. Spain, 2017, no. 32600/12.

33 M. Urbańczyk, Od godności dobrze urodzonych po egalitarne szlachectwo dla wszystkich. Szkice ze studiów nad idea godności cztowieka, in: "Czasopismo Prawno-Historyczne" 2014, vol. LXVI, issue 2, p. 183. See also idem, Liberalna doktryna wolności stowa a swoboda wypowiedzi historycznej, Wydawnictwo Poznańskie, Poznań 2009.

34 Treaty of Lisbon amending the Treaty on European Union and the Treaty establishing the European Community signed in Lisbon on 13 December 2007 (Journal o Laws of 2009 , no. 203, item 1569).

35 M. Klimkowski, Znaczenie zasady pomocniczości dla międzynarodowego systemu ocbrony praw cztowieka, in: Uniwersalny system ochrony praw cztowieka. Aksjologia. Instytucje. Efektywność, ed. J. Jaskiernia, Wydawnictwo Adam Marszałek, Toruń 2015, p. 191.

36 Application Margaret, Thomas, Mark, Alana, Michaela and Rossina Murray v. Great Britain, 1994 , no. 14310/88. 
above circumstances Article 8 of the ECHR was not breached, as the British authorities took justified and proportional action against an existing terrorist threat. ${ }^{37}$

In many countries at the moment there is an observable radicalisation of social moods. Attempts to counteract radicalisation should be broadened to encompass the prevention of hate speech in the media, the so-called "online radicalisation". ${ }^{38}$ The information space should not be directed and determined by terrorists. Lack of consistent action may lead to extremism and the spread of malignant forms of violence. Current reasons for radicalisation include the deteriorating economic situation, unemployment, and marginalisation and social exclusion due to ethnicity, gender, age, health condition and religion. The growing wave of migration constitutes another challenge for European countries. Therefore, it can be concluded that the fight against terrorism should also include actions for the improvement of the social situation, as well as the inclusion of individual persons as active participants in society.

\section{Concluding Remarks}

Ensuring that there is a diversity of ideas and opinions is a condition for the development of democratic society. Terrorists use the media to depreciate the law, the state and human rights, to manipulate society and generate a certain state of mind, as well as to deprive information of its pluralist nature. Freedom of expression should not be "decorative" in civil society, but a binding agent that joins and makes human rights the prime focus. Care for public safety cannot lead to indifference to the needs of individuals nor to the absolutisation of the interest of the state. The notion of the "common good" in the context of terrorism prevention should be referred through the essence of human rights.

Exercising freedom of speech objectively may provide protection against the ideological trap set by terrorists. The media constitute an important source of information about potential threats. Public discourse helps reach an objective perception of this subject matter. This prevents the creation of a multiplied image and a pseudo-reality. Freedom of speech should be an actually exercised right of an individual, as it creates a space of

37 C. Walker, Terrorism and the Law, Oxford University Press, Oxford 2011, pp. 145, 146-147. See. M. Vermeulen, Assessing Counter - Terrorism as a matter of Human Rights: Perspectives from European Court of Human Rights, in: The Impact, Legitimacy and Effectiveness of EU CounterTerrorism, eds. F. Londras, J. Doody, Routledge Research in Terrorism and the Law, Routledge Taylor Q Francis Group, London-New York 2015, p. 88.

38 Communication from the Commission to the European Parliament, the Council, the European Economic and Social and the Committee of the Regions supporting the prevention of radicalisation leading to violent extremism, Brussels, 14 June 2016 [COM (2016) 379], p. 8-9. See application Magyar Tartalomszolgáltatók Egyesülete and Index.hu v. Hungary, 2016, no. 22947/13 - hate speech online. 
expression, consolidates society in the face of danger, and motivates governments to take responsible action and not set "double standards" for human rights.

\section{Literature}

Aleksandrowicz T. R., Bezpieczeństwo w cyberprzestrzeni ze stanowiska prawa międzynarodowego, "Przegląd Bezpieczeństwa Wewnętrznego" 2016, no. 15 (8).

Balcerzak M., Ochrona osób w przypadku katastrof. Uwagi o projekcie Artykutów Komisji Prawa Międzynarodowego Organizacji Narodów Zjednoczonych, in: Kierunki rozwoju wspótczesnego prawa międzynarodowego, ed. K. Karski, Warszawa 2015.

Bodnar A., Szuleka M., Koncepcja „nadużycia prawa” w Konwencji o ochronie praw cztowieka i podstawowych wolności a mowa nienawiści, in: Mowa nienawiści a wolność stowa. Aspekty prawne i spoteczne, eds. R. Wieruszewski, M. Wyrzykowski, A. Bodnar, A. Gliszczyńska-Grabias, Warszawa 2010.

Brunst P. W., Terrorism and the Internet: New Threats Posed by Cyberterrorism and Terrorist Use of the Internet, in: A War on Terror? The European Stance on a New Threat, Changing Laws and Human Rights Implications, eds. M. Wade, A. Maljevic, New York 2010.

Chomiczewski K., Zagrożenie użyciem broni biologicznej w zamachach terrorystycznych, in: Oblicza wspótczesnego terroryzmu, eds. K. Kowalczyk, W. Wróblewski, Toruń 2006.

Czapliński W., Wyrozumska A., Prawo międzynarodowe publiczne. Zagadnienia systemowe, Warszawa 2014.

Gadkowski T., Problematyka samoobrony na tle zakazu użycia sity zbrojnej w prawie międzynarodowym, in: "Ruch Prawniczy, Ekonomiczny i Socjologiczny" 2013, issue 3.

Gliszczyńska-Grabias A., Ograniczenia swobody wypowiedzi-klauzule imitacyjne z art. 19 ust. 3 MPPOiP, in: Międzynarodowy Pakt Praw Obywatelskich (Osobistych) i Politycznych. Komentarz, ed. R. Wieruszewski, Warszawa 2012.

Gliszczyńska-Grabias A.,Zakazpropagandywojennej, in:MiędzynarodowyPakt Praw Obywatelskich (Osobistych) i Politycznych. Komentarz, ed. R. Wieruszewski, Warszawa 2012.

Hoffman B., Oblicza terroryzmu, Warszawa 2001.

Kamiński I. C., Ograniczenia swobody wyporwiedzi dopuszczalne w Europejskiej Konwencji Praw Cztowieka. Analiza krytyczna, Warszawa 2010.

Klimkowski M., Znaczenie zasady pomocniczości dla międzynarodowego systemu ochrony praw cztowieka, in: Uniwersalny system ochrony praw cztowieka. Aksjologia. Instytucje. Efektywność, ed. J. Jaskiernia, Toruń 2015.

Kowalska S., Prawa cztowieka a terror i terroryzm, Kalisz 2008.

Eadem, $W$ poszukiwaniu ochrony przed bezprawnościq i arbitralnościq - strasburskie standardy praw cztowieka, Poznań 2014. 
46 | Adam Mickiewicz University Law Review

Kowalski M., Prawo do samoobrony jako środek zwalczania terroryzmu międzynarodowego, Warszawa 2013.

Macovei M., Freedom of Expression. A Guide to the Implementation of Article 10 of the European Convention on Human Rights, Strasbourg 2004.

Redelbach A., Wolnośc stowa w orzecznictwie Europejskiego Trybunatu Praw Cztowieka, in: "Ruch Prawniczy, Ekonomiczny i Socjologiczny" 2000, issue 3.

Sobczak J., Prawo do wizerunku, prywatności i godności wobec wolności stowa, in: "Annales Universitatis Mariae Curie-Skłodowska. Sectio K: Politologia”2008, vol. XV, no. 1.

Urbańczyk M., Liberalna doktryna wolności stowa a swoboda wypowiedzi historycznej, Poznań 2009.

Idem, Od godności dobrze urodzonych po egalitarne szlachectwo dla wszystkich. Szkice ze studiów nad idea godności cztowieka, in: "Czasopismo Prawno-Historyczne" 2014, vol. LXVI, issue 2.

Vermeulen M., Assessing Counter - Terrorism as a matter of Human Rights: Perspectives from European Court of Human Rights, in: The Impact, Legitimacy and Effectiveness of EU Counter - Terrorism, eds. F. Londras, J. Doody, London-New York 2015.

Wacławczyk W., Swoboda wypowiedzi jako prawo cztowieka, in: Prawa cztowieka. Wybrane zagadnienia i problem, eds. L. Koba, W. Wacławczyk, Warszawa 2009.

Walker C., Terrorism and the Law, Oxford 2011.

Act of 6 September 2001 about Access to Public Information (Dz.U. 2001, no. 112, item 1198 as amended).

Communication from the Commission to the European Parliament, the Council, the European Economic and Social and the Committee of the Regions supporting the prevention of radicalisation leading to violent extremism, Brussels, 14 June 2016 [COM (2016) 379].

Constitution of the Republic of Poland of 2 April 1997 (Dz.U. 1997, no. 78, item 483).

Convention for the Protection of Human Rights and Fundamental Freedoms singed in Rome on 4 November 1950 (Dz.U. 1993, no. 61, item 284).

Convention on the Prevention and Punishment of Crimes Against Internationally Protected Persons, Including Diplomatic Personnel prepared in New York on 14 December 1973 (Dz.U.1983, no. 37, item 168).

Convention on Environmental Impact Assessment in a Transboundary Context signed in Espoo on 25 February 1991 (Dz.U. 1999 , no. 96, item 1110).

International Covenant on Civil and Political Rights open for signature in New York on 19 December 1966 (Dz.U. 1977, no. 38, item 167).

The Charter of the United Nations (UNC) signed on 26 June 1945 in San Francisco (Dz.U. 1947, no. 23, item 90). 
The Declaration of Rio de Janeiro on Environment and Development, The United Nations Conference on Environment and Development was organised in Rio de Janeiro 3-14 June 1992.

Treaty of Lisbon amending the Treaty on European Union and the Treaty establishing the European Community signed in Lisbon on 13 December 2007 (Journal o Laws of 2009 , no. 203, item 1569).

\section{SUMMARY}

\section{Freedom of Speech in the Face of Terrorism - Selected International Law Regulations}

The essay presents freedom of speech from the perspective of international law regulations. The phenomenon of terrorism is one of the most asymmetrical, amorphous and hybrid threats to international security and human rights. The author discusses freedom of speech in the context of anti-terrorism measures. Freedom of speech is a legal and axiological framework of democratic society. The media constitute an important source of information about social pathologies and threats. Terrorists use the media to depreciate the law and the state, and to generate chronic fear in society. The essay stresses the fact that a rational and informed approach to human rights should serve as a reference point for anti-terrorism. However, one cannot limit individual freedom in an arbitrary way. Public discourse helps reach an objective perception. This prevents the creation of a multiplied image, pseudo-reality and "double standards" for freedom of speech.

Keywords: freedom of speech, terrorism, anti-terrorism, international law, human rights

Samanta Kowalska, Adam Mickiewicz University in Poznań, Faculty of Pedagogy and Fine Arts in Kalisz, St. Nowy Świat 28-30, 62-800 Kalisz, Republic of Poland, e-mail: skowalsk@amu.edu.pl. 
